UC-10

Issued: September 1985

LA --10457

DE86 003284

\title{
Recovery of Plutonium by Pyroredox Processing
}

\author{
James A. McNeese \\ David F. Bowersox \\ Dana C. Chrisiensen
}

\section{DISCLAIMER}

This report was prepared as an account of work sponsored by an agency of the United States Government. Neither the United States Government nur any agency thereof, nor any of their employees, makes any warranty, express or implied, or assumes any legal liability or responsibility for the accuracy, completeness, or usefulness of any information, apparatus, product, or process disclosed, or represents that its use would not infringe privately owned rights. Reference herein to any specific commercial product, process, or service by trade name, trademark, manufacturer, or otherwise does not necessarily constitute or imply its endorsement, recommendatior, or favaring by the United States Government or any agency thereof. The views and opinions of authors expressed herein do not necessarily state or reflect those of the United States Government or any azency thereof.

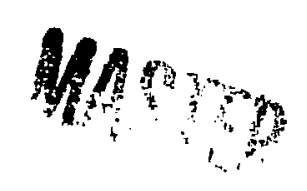




\title{
RECOVERY OF PLUTONIUM BY 'YROREDOX PROCESSING
}

\author{
by \\ James A. McNeese, Dayid F. Bowersox. \\ and Dana $C$. Christensen
}

\begin{abstract}
Using pyrochemical oxidation and reduction, we have developed a process to recover the plutonium in impure scrap with less than $95 \%$ plutonium. This pluxonium metal was further purified by pyrochemical electrorefining. During development of the procedures, depleted electrorefining anodes were processed, and over $80 \%$ of the plutonium was recovered as high-purity metal in one electrorefining cycle. Over $40 \mathrm{~kg}$ of plutonium has been recovered from $55 \mathrm{~kg}$ of impure anodes with our procedures.
\end{abstract}

\section{INTRODUCTION}

The purpose of pyrochemical research and development programs is to examine new techniques for producing high-purity plutonium metal from impure oxides, metals, and scrap. Los Alamos has demonstrated pyrochemical processes by taking plutonium scrap, converting it to oxide. and then, through a series of operations, producing high-purity plutonium metal. ${ }^{1}$ The last purification step. electroretining. is most effective when the metal feed exceeds $95 \%$ plutonium. We developed the pyroredox process to upgrade the scrap of low plutonium content to mert the feed requirements for effective electrorefining.

The two basic steps for the pyroredox process are oxidation.

$$
2 \mathrm{Pu} \text { (impure) }+3 \mathrm{znCl}_{2} \frac{\mathrm{ZnCl}_{2}-\mathrm{KCl}}{750^{\circ} \mathrm{C}} 3 \mathrm{Zn}+2 \mathrm{PuCl}_{3}
$$

and reduction.

$$
2 \mathrm{PuCl}_{3}+3 \mathrm{Ca} \underset{850^{\circ} \mathrm{C}}{\stackrel{\mathrm{CaCl}_{2}}{\longrightarrow}} 2 \mathrm{Pu}+3 \mathrm{CaCl}_{2} .
$$

The plutonium product can be separated mechanically from the salt and cycled into our primary pyroprocessing facility. This oxidation-reduction scheme was initially pro; osed and studied by J. G. Reavis* for reprocessing plutonium reactor fuels. In his research, zinc chloride in molten sodium chloride oxidized plutonium milal is the trichloride salt, and, in a second step, calcium was added to reduce the plutonium to metal. J. B. Knighton and coworkers at the Rocky Flats Plant ${ }^{3}$ have also studied these reactions.

The pyroredox process upgrades lower-purity plutonium metal sciap for electrorefining. However, our principal application has been for spent anodes containing plutoniurn, gallium, and other less electropositive elements. The major impurity is usually gallium, which is added in casting to ensure a critically safe anode during electrorefining. ${ }^{4.5}$ As electrorefining takes place, plutonium is oxidized from the anode rool into the molten eutectic salt and migrates to the cathode. There it is reduced to high-purity metal and drips into the annular chamber of the cell. Under the conditions of the process, elements less electropositive than plutonium

*See Ref. 2 and J. G. Reavis. "Fused Salt Oxidation-Reduction Process for Plutonium Recycle Fuel." AIME. Detroit. Michigan, October 1961. 
remain in the anode pool. The run is automatically terminated when this pool solidifies (at about 90\%. plutonium depletion). Although the plutonium remaining in these anodes can be recovered by aqueous reprocessing, ${ }^{6}$ we believe that pyroredox is far moie compact, rapid, and efficient. Most of the experiments described in this report were conducted with spent anodes. Additional work with plutonium and simulated scrap, however, indicates that our conclusions are valid for other low-grade mixtures of plutonium.

\section{EXPERIMIENTAL PROGRAM}

\section{A. Equipment}

The description of equipment used in this program has been published previously.' A typical experimental seiup is shown in Fig. I. Reactions take place in an inner crucible, usually constructed of tantalum or magnesia to minimize reagent attack. The crucible is centered in thi heat zone of a 15 -cm-diameter clam-shell furnace. Safety containers of stainless steel or tantalum are placed around the reaction crucible to catch any leakagt:-

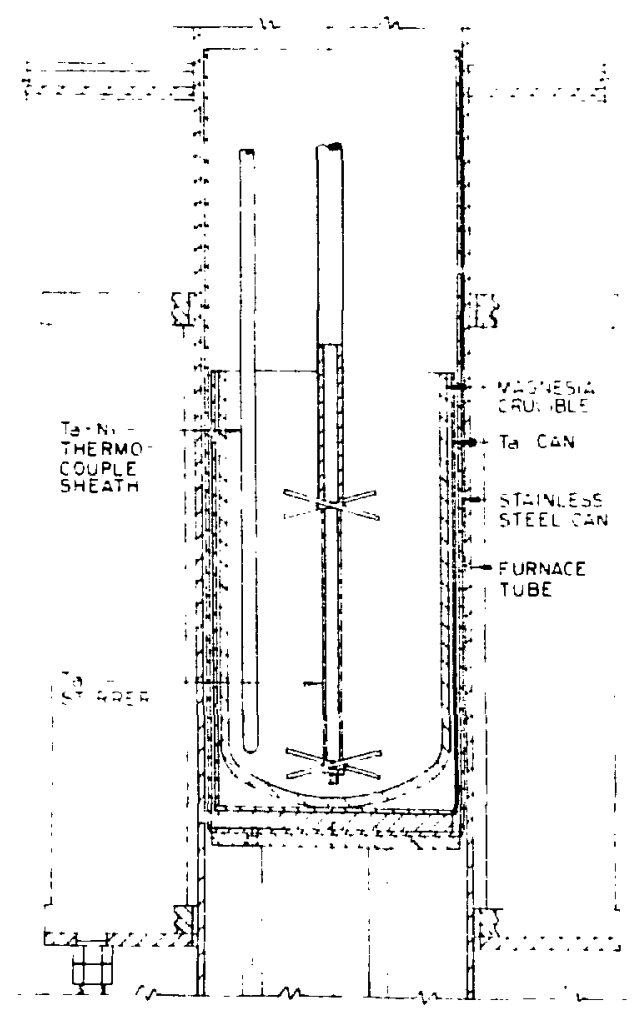

Fig. 1. Experimental apparalus.
In addition, the stainless steel furnace tube is extended below the furnace is provide a cool area in which to collect and freeze any molten products in case of a catastrophic leak at higher temperatures. Type $\mathrm{K}$ thermocouples, enclosed in a double-walled tantalumnickel thermocouple well, measure temperature in the melt. Small microprocessor units prcgiam and monitor temperature profiles.

\section{B. Reagents}

In the oxidation process, dried Baker's analytical reagent grade zinc chloride and potassium chloride are mixed at a 31-moi'\% zinc chloride ratio. placed in a large pyrex reaction tube, and melted. The melt is sparged with anhydrous hydrogen chloride for $1 \mathrm{~h}$, flushed with dry argon, and, finally, filtered (in an argon atmosphere) through a coarse pyrex frit and a heated quartz transfer tube into a pyrex crucible. The white eutectic is sealed in a plastic bag in an argon atmosphere and stored in argon until needed This salt, which melts at $462^{\circ} \mathrm{C}$, met purity requirements and was sufficiently moisture-free to prevent foaming during oxidation reactions.

For the reduction process, Malinckrodt food grade calcium chloride was vacuumi-dried at $225^{\circ} \mathrm{C}$ for a minimum of 5 days and placed in a platinum crucible for purification. The salt and crucible were placed in a stainless steel furnace tube; the equipment was assembled and the system heated to $800^{\circ} \mathrm{C}$. Anhydro's hydrogen chloride was passed through the mel 6 for $2 \mathrm{~h}$. An argon purge followed. The melt was then traisferred through a heated tantalum tube into an erbia-coated, split mold of stainless stcel. The resulting salt cast was sealed into a plastic bag and stored in argon until needed.

Pfitzer triple-distilled calcium was pressed into an ingot of $\sim 80 \%$ theoretical density to reduce the surface area and, consequently, the rate oi reaction in the reduction sequence.

\section{Procedures}

For the oxidation step, depleted anodes were placed in a tantalum crucible, and $10 \%$ excess zinc chloride (calculated) was added as a $31-\mathrm{mol}_{0} \mathrm{ZnCl}_{2}-\mathrm{KCl}$ eutecic. The system was assembled, evacuated, backfilled with argon, and heatcd to the salt meli at $462^{\circ} \mathrm{C}$. The stirrer and thermocouple well were lowered into the molten salt. The melt was stirred while heating to $750^{\circ} \mathrm{C}$. After $\mathrm{l} \mathrm{h}$ at temperature, the mixture was heated and kept at $850^{\circ} \mathrm{C}$ for $\mathrm{l}$ h to promote phase separation. The stirrer and thermocouple well were then raised from the melt. After another $4 \mathrm{~h}$ at temperature, the system was cooled at a $200^{\circ} \mathrm{C} / \mathrm{h}$ rate to ambient temperature. The two-phase product was removed, and the lighter salt phase was mechanically separated from the zinc button. 
For the reduction step, the salt from the oxidation reaction was crushed and mixed with $\mathrm{l} \mathrm{kg}$ of dried calcium chloride. The calculated amount of calcium was added as a pressed ingot; the mixture was placed in a magnesia crucible and the vessel assembled. The vessel was evacuated, backfilled with argon, and heated to salt melt at about $700^{\circ} \mathrm{C}$. The thermocouple well and the stirier were then lowered into the liquid, and the mixture was stirred. During the reaction, the temperature rose gradually to $850^{\circ} \mathrm{C}$; after $20 \mathrm{~min}$, the stirrer and thermocouple well were raised above the melt. The system was maintained at $850^{\circ} \mathrm{C}$ for $15 \mathrm{~min}$, then cooled without power to ambient temperature. The product was broken out of the crucible for liquation or mechanical separation of the phases.

\section{RESULTS AND CONCLUSIONS}

\section{A. Oxidation}

As shown in E4. (i), the main reactions in oxidation are forming plutonium trichloride in the salt phase while reducing zinc chloride to zinc metal. The free energies of formation of selected chlorides are listed in Table I. All chlosides with energies higher than zinc should be oxidized with the plutonium intr: the stlt phase. Those impurities with lower energies concentratc in the zinc phase. if equilibrium conditions are met. aluminum, americium, uranium, and the rare earths would transfer into the salt phase with plutonium. Iron. tantalum, and gallium would concentrate in the zincrich metal phase.

In our experiments, the oxidation was exothermic. The rate and temperature were controllec by slowing the stirring rate. As a result, foaming and overflow from the crucible were eliminated. After the postreaction heat cycie $\left(5 \mathrm{~h}\right.$ at $\left.850^{\circ} \mathrm{C}\right)$, good phase separation occurred (Fig. 2). The relatively slow cooling rate promoted shrinkage of the product from the crucible walls so that the tantalum crucible could be reused. With simulated anodes containing more than $95 \%$ plutonium as feed, a green salt, most likely $\mathrm{K}_{3} \mathrm{PuCl}_{6}$ in a potassium chloride matrix, and a bottom metal phase of zinc formed. After these phases were mechanically scparated. the zinc phase could be discarded (Fig. 3). The green salt was then reduced to plutonium metal.

\section{B. Reduction}

The main reactions in reduction of the green salt are the reduction of tripositive plutonium to the metal and oxidation of calcium to calcium chloride (Eq. 2). However, the excess zinc chloride added for the oxidation step is also reduced

$$
\mathrm{ZnCl}_{2}+\mathrm{Ca} \longrightarrow \mathrm{CaCl}_{2}+\mathrm{Zn} .
$$

Table I. Behavior of Impurity Elements.

\begin{tabular}{cc}
\hline Element & $\begin{array}{c}-\Delta F^{\circ} \\
\text { Atom Ci } \\
\text { (kcal/g) }\end{array}$ \\
\hline $\mathrm{Ir}$ & $\mathbf{2}$ \\
$\mathbf{W}$ & $\mathbf{5}$ \\
$\mathrm{Ni}$ & $\mathbf{1 8}$ \\
$\mathrm{Cu}$ & 21 \\
$\mathrm{Ta}$ & $\mathbf{2 7}$ \\
$\mathrm{Pb}$ & 27 \\
$\mathrm{Fe}$ & 27 \\
$\mathrm{Si}$ & $\mathbf{2 8}$ \\
$\mathrm{Cd}$ & 30 \\
$\mathrm{Cr}$ & 32 \\
$\mathrm{Ga}$ & $\mathbf{3 2}$ \\
$\mathrm{Zn}$ & $\mathbf{3 4}$ \\
$\mathrm{Mn}$ & $\mathbf{4 1}$ \\
$\mathrm{Ti}$ & $\mathbf{4 3}$ \\
$\mathrm{Al}$ & $\mathbf{4 6}$ \\
$\mathrm{U}$ & $\mathbf{5 4}$ \\
$\mathrm{Np}$ & $\mathbf{5 5}$ \\
$\mathrm{Zi}$ & $\mathbf{5 6}$ \\
$\mathrm{Mg}$ & $\mathbf{5 8}$ \\
$\mathrm{Th}$ & $\mathbf{5 9}$ \\
$\mathrm{Pu}$ & $\mathbf{5 9}$ \\
$\mathrm{Ce}$ & $\mathbf{6 6}$ \\
$\mathrm{Am}$ & $\mathbf{6 7}$ \\
$\mathrm{Na}$ & $\mathbf{7 6}$ \\
$\mathrm{Ca}$ & 77 \\
$\mathrm{Li}$ & 78 \\
$\mathrm{~K}$ & $\mathbf{8 2}$ \\
\hline \hline
\end{tabular}

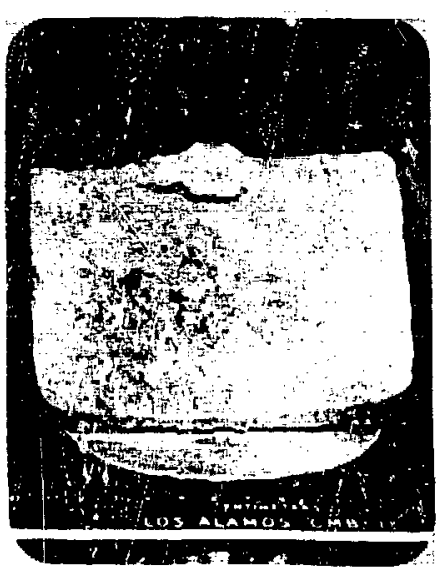

Fig. 2. Oxidation product and residue. 


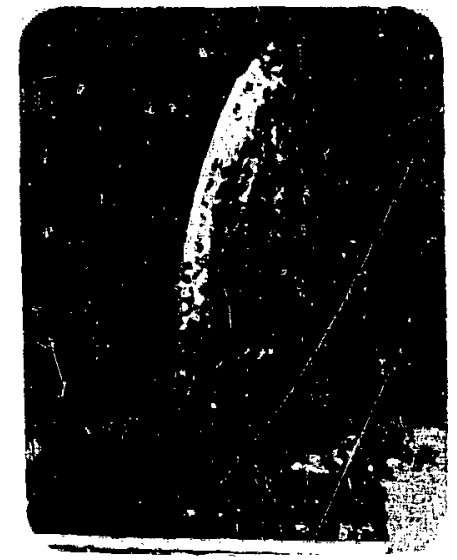

Fig. 3. Zinc metal residuc containeng gallium and uher metalix impurites

The reduction is slowed by adding $1000 \mathrm{~g}$ of dried calcium chloride to the green salt prior to heating, using pressed calcium, and stirring siowly at a rate lower than $200 \mathrm{rpm}$. The calcium chloride addition adsorbs calcium oxide formed in reactions and also minimizes formation of black salts. Yiclds are usually greater than $98 \%$ and, under optimum conditions, have reached calculated alues ci $99.5 \%$. Results showing the purification attained by the two-step process are given in Table II. the high zinc and aluminum concentrations do not interfere with further purification by electrorefining.

In most cases, the reduction product was a salt phase over a two-phase button (Fig. 4). The salt phase was discarded. The bottom, denser phase was mainly plutonium and contained small amounts of calcium and zinc. The upper metal phase was typically $50-60 \%$ plutonium. $10-25 \%$ zinc. and $4 \%$ calcium. Several buttons were collected and coalesced to consolidate phase separation into a less tirne-consuming procedure. This step, liquation, is discussed below.

\section{Additional Processing Steps}

To recover spent anodes containing gallium and the impurities that collect in the anode during electrorefining. additional proressing steps were necessary.

\section{Processing}

When we processed spent anodes rather than plutonium-gallium mixtures, three phases formed during oxidation. The upper phasi (a jrecn salt) and the bottom phases (metallic zinc) were similar to phases obtained with the simulated anodes. The third (intermediate)

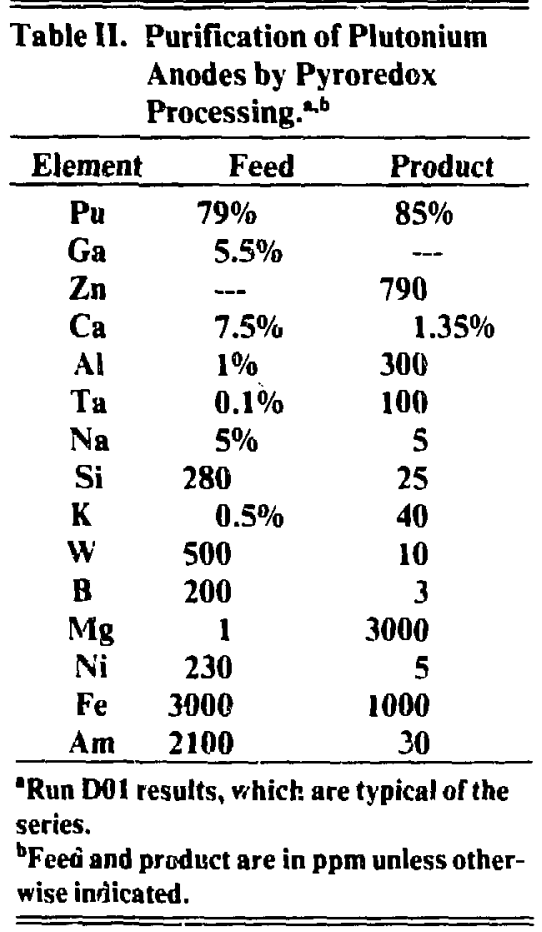

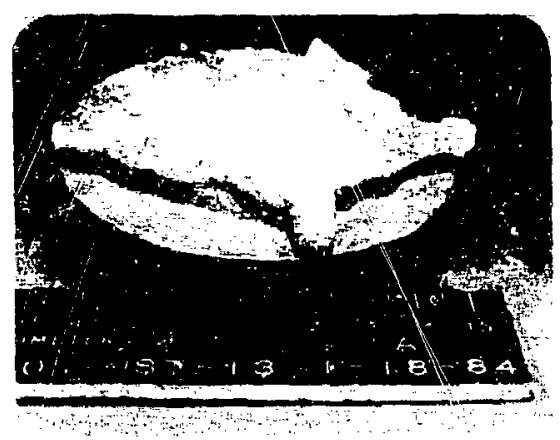

Fig. 4. Two-phase metal product.

phase was a grey salt that we attributed to impurities in the anude. It consisted mainly of a fog of uncoalesced zinc in the salt matrix with some evidence of plutonium oxvchloride formation. This third phase was minimized by a polishing step prior to the oxidation of the anode. The spent anode, $300 \mathrm{~g}$ of calcium, and $3000 \mathrm{~g}$ of calcium chloride were placed in a magnesia reaction crucible. The reaction system was assembled, evacuated, and backfilled with argon. The system was heated to $800^{\circ} \mathrm{C}$, and stirring was begun and increased from 200 to $600 \mathrm{rpm}$ as the temperature rose to $850^{\circ} \mathrm{C}$. 
As shown in Fig. 5, the product was homogeneous. Plutonium losses during polishing were quite low (less than $5 \mathrm{~g}$ ), and the metal button could be transferred for the oxidation step. Polishing markedly reduced grey salt formation, probably by reducing any partially nxidized species in the spent anode. Additional zinc chlor ude was now needed, however, to oxidize both the plutonium and the excess calcium contained in the button. Yields in the oxidation step increased to greater than $80 \%$ after polishing.

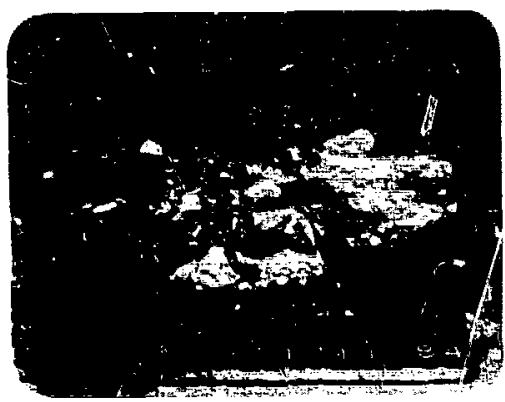

Fig. 5. Polished anude

\section{Liquation}

Liquation removes zinc and calcium from the reduction product while preparing most of the plutonium for further purification. The liquation step is a gravity separation of the two-phase button formed in the reduction. Several of these buttons. totaling $4.5 \mathrm{~kg}$, were placed in a long. narrow magnesia crucible. The reaction system was asscrivitu. evacuated, and backfilled with argon. The vessel was heated and maintained at $850^{\circ} \mathrm{C}$ for $6 \mathrm{~h}$. The resulting ingot consisted of a lighter upper phase and a more dense plutonium-rich lower phase (Fig. 6). Results of several liquations are summarized in Table III. The bottom phase containing most of the plutonium could be electrorefined without further treatment. The upper phase was recycled to the oxidation step for removal of calcium and zinc.

\section{The Electrorefined Product}

Even though electrorefining is a mature process, we demonstrated the liquated buttons could be further processed to high-purity metal. Table IV summarizes data from experiments in which the denser phase from the liquation step was electrorefined. Yields were satisfactory: purity of the product ring was excellent (see Table V).

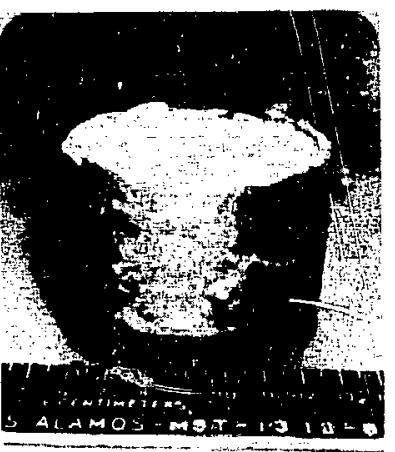

Fig. 6 Lower phase from liquation.

Table III. Composition of Liquation Phase.

\begin{tabular}{|c|c|c|c|c|c|c|c|c|}
\hline \multirow{3}{*}{$\begin{array}{c}\text { Experiment } \\
\text { No. }\end{array}$} & \multicolumn{2}{|c|}{ Plutonium } & \multicolumn{2}{|c|}{ Calcium } & \multicolumn{2}{|c|}{ Zinc } & \multirow{2}{*}{\multicolumn{2}{|c|}{$\begin{array}{r}\text { Density } \\
\left(\mathrm{g} / \mathrm{cm}^{3}\right) \\
\end{array}$}} \\
\hline & Top & Bottom & Top & & Top & & & \\
\hline & $(\%)$ & $(\%)$ & $(\%)$ & Bottom & $(\%)$ & Bottom & Top & Bottom \\
\hline 1 & 42 & 89 & 5 & $130 \mathrm{ppm}$ & 8 & 600 ppm & 5.7 & 15.6 \\
\hline 2 & 0.7 & 93 & 20 & 700 ppm & 30 & $0.4 \%$ & 2.5 & 15.0 \\
\hline 3 & 55 & 95 & 51 & --- & 12.5 & --- & -- & --- \\
\hline 4 & 47 & 90 & 24 & $1.8 \%$ & 15.5 & $3.5 \%$ & -- & -- \\
\hline
\end{tabular}


Table IV. Results of Liquation Experiments.

\begin{tabular}{lccc}
\hline & & \multicolumn{2}{c}{ Phase } \\
\cline { 2 - 4 } & Ingot & Top & Bottom \\
\hline Pu, g & 4340 & 1220 & 3120 \\
Total Pu, \% & 99.3 & 28.1 & 71.9 \\
Density, g/cm & -- & 7.5 & 15 \\
\hline
\end{tabular}

\begin{tabular}{lcc}
\hline \hline Table V. & \multicolumn{2}{c}{$\begin{array}{l}\text { Product of Electrorefining } \\
\text { Pyroredox Mletal. }\end{array}$} \\
\hline & \multicolumn{3}{c}{ Plutonium Content } \\
Component & $(\mathrm{g})$ & $(\%)$ \\
\hline Product Ring & $\mathbf{4 0 8 1}$ & $\mathbf{7 8 . 4}$ \\
Shot & 26 & 0.5 \\
Cathode & 9 & 0.2 \\
Crucible & 83 & 1.6 \\
Salt & 671 & 12.9 \\
Anode & 334 & 6.4 \\
Yield" & - & 80.1 \\
\hline "Yield $=100 X$ (Pu ring + shot)/Pu feed. \\
\hline
\end{tabular}

\section{SLMMARI}

We have developed a method for removing impurities from plutonium scrap that contains less than $95 \%$ plutonium so that it meets the $95 \%$-purity criterion for effective electrorefining. The process consists of oxidation of plutonium to the trichloride followed by reduction to metal. The flow diagram (Fig. 7) shows the process, as modified for recoveririg plutonium from spent anodes in our production demonstration facility. The liquated product has been purified by electrorefining. Yields from pyroredox processing in our demonstration facility are greater than $80 \%$. We believe that the process is ready for transfer to production facilities.

The $31 \mathrm{~mol} \% \mathrm{ZnCl}_{2}-\mathrm{KCl}$ eutectic was successfully prepared in $5-\mathrm{kg}$ batches by drying, heating to a melt, filtering through a coarse pyrex frit, and transferring the melt into a warm quartz crucible. The moisture-free salt did not froth or overflow during the oxidation step.

Prepolishing and liquation were effective steps for treating the impure spent anodes to adapt the general. generic process to our specific requirements.

We are studying methods for minimizing or eliminating the grey salt phase that forms during oxidation. We recycle this phase when necessary.

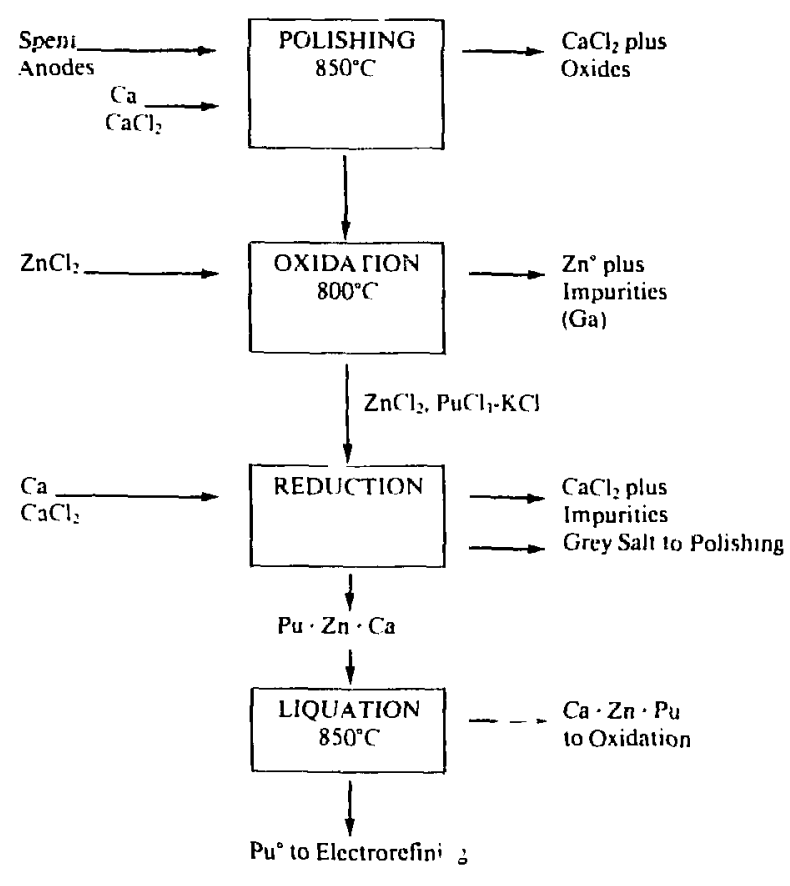

Fig. 7. Pyroredox process for recovery of plutonium from impure scrap.

\section{REFERENCES}

1. D. C. Christensen and L. J. Mullins, "Plutonium Metal Production and Purification at Los Alamos," in Plutonium Chemistry, W. T. Cornall and G. R. Chopkin, Eds. (ACS Symposium Series, American Chemical Society, New York, 1983), pp. 409-432.

2. J. G. Reavis and J. A. Leary, "Nonaqueous Dissolution of Massive Plutonium," US Patent No. 2,886,410, May 12, 1959.

3. J. B. Knighton, R. G. Auge, and J. C. Brown, "Purification of Plutonium by Oxidation-Reduction Process," RFP-1691-A, in "Research and Development Annual Progress Report, November 1, 1980 to September 30, 1981," Frend John Minor, Ed., Rockwell International, Rocky Flats Plant, Golden, Colorado (August 11, 1982).

4. L. J. Mullins and J. A. Leary, "Fused Salt Electrorefining of Molten Plutonium and Its Alloys," Los Alamos Scientific Laboratory report LA-3118 (November 1964). 
5. L. J. Mullins, J. A. Leary, A. N. Morgan, and W. J. Maraman, "Plutonium Electrorefining," Ind. Eng. Chem. Process Des. Develop. 2, 20 (1963).

6. C. E. Baldwin and J. D. Navratil, "Plutonium Process Chemistry and Rocky Flats." in Plutonium Chemistry, W. T. Carnall and G. R. Choppin. Eds. (ACS Symposium Series. American Chemical Society, New York. 1983), pp. 369-380. 